\title{
THE USE OF TRAWL, GRAB AND CAMERA IN ESTIMATING MARINE BENTHOS
}

\author{
By A. D. McIntyre \\ Scottish Home Department, Marine Laboratory, Aberdeen
}

(With Plates I-IV and Text-fig. I)

Certain animals of the epifauna, because of their distribution over the bottom, are often difficult to sample quantitatively. They may occur as individuals widely dispersed over a large area, or they may be present in dense aggregations which themselves have a patchy distribution. In the past, workers have tried to estimate the numbers of such animals by the combined use of trawls and grabs of various types. The post-war development of underwater photography suggests that the camera will be a useful additional tool (e.g. Vevers, 1951, 1952). During the testing of an underwater camera from Aberdeen an opportunity was taken to compare the estimates of some of the larger epifauna from grab and trawl hauls with estimates derived from underwater photographs. The results are described in this paper.

\section{THE GeAR}

A $\frac{1}{10} \mathrm{~m}^{2}$ Van Veen type grab, weighted to $72 \mathrm{lb}$. $(33 \mathrm{~kg})$ and fitted with the endless warp rig, was used. The trawl was a standard Agassiz with a $6 \mathrm{ft}$. $(182 \mathrm{~cm})$ beam. The underwater equipment for the camera was designed by Mr R. E. Craig. The unit was a Royal Air Force F-24 camera using $5 \frac{1}{2}$ in. aerofilm giving negatives of roughly $\mathrm{I} 3 \times \mathrm{II} \mathrm{cm}$. Light was provided by an electronic flash apparatus, and a yellow filter was used. Technical details of this equipment are not discussed here.

\section{METHODS}

The work was carried out in Loch Creran, and in the Lynn of Lorne, near Oban in Argyllshire. Dans were set out marking five stretches varying in length from $4 \mathrm{I} 7$ to $I I 74 \mathrm{~m}$. The positions of these stretches are shown in Text-fig. I. On each stretch a similar procedure was followed. First the ship was allowed to drift between the two dahns while a series of photographs was taken. At the beginning of the run the camera was lowered to the bottom, and was raised a few feet after each exposure to allow the equipment to recharge. Recharging generally took about $30 \mathrm{sec}$, so that a continuous series of photographs was taken over the ground at a rate of one exposure per minute. The ship was then allowed to drift over the same ground while a series of grab 
hauls was made. Finally, the Agassiz trawl was towed between the two dans. Since the distance between the dahns was so short, it was fairly certain that between any two sets the three gears covered the same ground, and this was confirmed by an examination of traces from the ship's echo-sounder, which was run continuously.

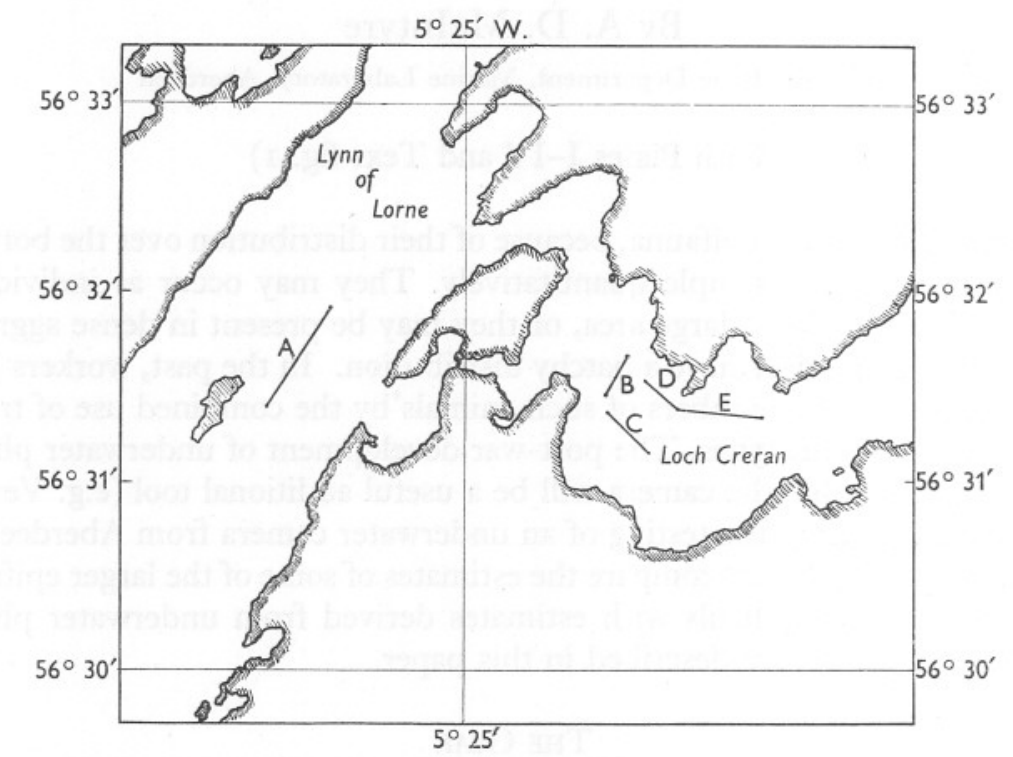

Text-fig. I. Chart of the area studied, showing the positions of the five stations. From Admiralty Chart No. 28I4A.

All the larger animals of the epifauna caught by trawl and grab were counted and identified. The nomenclature used is that in the Plymouth Marine Fauna (Marine Biological Association, I93I). In dealing with photographic data, series of approximately $2 \mathrm{I} \times \mathrm{I} 7 \mathrm{~cm}$ prints were made. Each print represented almost I $\mathrm{m}^{2}$ of bottom, but since the focus often deteriorated towards the edges the prints were masked, and animals on a $\frac{7}{10} \mathrm{~m}^{2}$ area were counted.

\section{RESULTS}

Details of the estimates by the three gears are given below for each ground separately. The Agassiz trawl catches are summarized in Table I.

$$
\text { Stretch } A(\mathrm{Pl} \text {. IA) }
$$

This was in the Lynn of Lorne in $22-28 \mathrm{~m}$. The dans were II $74 \mathrm{~m}$ apart, and the ground was covered by seventy-two photographs and twenty-one grab hauls, as well as the Agassiz haul. The total area of bottom considered, i.e. the area swept by the trawl, was $2147 \mathrm{~m}^{2}$. 


\section{Table I. Numbers of Animals taken in each Stretch by the AgASSIZ TRAWL}

\begin{tabular}{|c|c|c|c|c|c|}
\hline Animal & A & $\mathrm{B}$ & $\mathrm{C}$ & $\mathrm{D}$ & $\mathrm{E}$ \\
\hline Ophiothrix fragilis & 1093 & I992 & 215 & 524 & 290 \\
\hline Asterias rubens & 2 & 5 & 2 & - & IO \\
\hline Other Asteroidea & 3 & 5 & 2 & - & 7 \\
\hline Echinoidea & 24 & 36 & 20 & I & I8 \\
\hline Chlamys opercularis & 23 & 4 & 27 & I2 & II 8 \\
\hline Lima & - & 83 & 35 & 8 & 5 \\
\hline Other Mollusca & - & 2 & 3 & 2 & 42 \\
\hline Decapoda reptantia & I7 & 29 & 20 & 29 & 84 \\
\hline Decapoda natantia & - & 5 & 38 & 38 & I4 \\
\hline Ascidians & - & 45 & $2 \mathrm{I}$ & 6 & I4 \\
\hline Fish & 8 & 2 & I & 4 & I6 \\
\hline
\end{tabular}

As shown by the photographs, the north end of the ground was of uniform sand, which merged about half-way along the stretch into a short area of coarser sand and gravel. This gave place to mud (Pl. IB) which covered most of the second half of the stretch, with the exception of a few patches here and there where shells, mostly of Cyprina islandica, were mixed with the mud. The main animals of the epifauna are considered below.

Ophiothrix fragilis was the most abundant animal encountered, but photographs showed it to be confined to the stretch of sand and gravel, occurring in the mud area only on the shell patches. Even on the hard ground, however, the distribution of Ophiothrix was by no means uniform. It occurred on each of the first thirty prints, ranging from one to sixty individuals per frame, with an average of thirty-three. The following nine prints, although over apparently similar ground, showed no Ophiothrix, but just before the beginning of the muddy ground they again appeared, with an average of eighteen per print. Knowing the number of photographs taken, it is possible to calculate that the sandy stretch was $650 \mathrm{~m}$ long, so that the Agassiz on this part swept an area of $\mathrm{II} 90 \mathrm{~m}^{2}$. Eleven of the grab samples came from this area, and all except two contained Ophiothrix, the mean number being I. 6 per sample. From the photographs the estimated number of Ophiothrix in the sand was 39,542, from grabs, I9,4I8, and the total number taken in the trawl was I093. The trawl value may be an overestimate for the sandy area alone, since it is assumed that all the Ophiothrix in the trawl were taken on this part.

On this stretch, as well as inside Loch Creran, small numbers of other ophiuroids (e.g. Ophiocomina nigra and Ophiopholis aculeata) were found mixed with the Ophiothrix populations.

Ophiura texturata, although slightly more abundant on the hard ground than on the soft, occurred over the whole stretch, and was seen on fifty-four of the seventy-two prints in numbers ranging from $I$ to 7 per print. Single specimens were found in four grab samples, but none was taken by trawl. 
From the photographs we can calculate that the total number of Ophiura present on the area swept by the trawl was 5325 , while the comparable value from the grab data is 4090 .

The seventeen kinds of decapoda reptantia found in the trawl consisted of four Munida bamffica, one small Galathea, nine small spider crabs (mostly Inachus) and three Eupagurus prideauxi. These same types were also seen on the photographs-a total of eight decapods on seven prints distributed over both the sand and the mud. The grab took one Eupagurus. Since the numbers are small it would be misleading to compare estimates for the whole stretch without taking into account the different areas sampled by each gear. The comparison is shown below:

$\begin{array}{lcc}\text { Gear } & \text { Area sampled } & \text { Estimate for stretch } \\ \text { Grab } & 2 \mathrm{~m}^{2} & \text { IO74 decapods } \\ \text { Camera } & 50 \mathrm{~m}^{2} & 34 \mathrm{I} \text { decapods } \\ \text { Trawl } & 2 \mathrm{I} 47 \mathrm{~m}^{2} & \text { I7 decapods }\end{array}$

Twenty-three small specimens of Chlamys opercularis were taken in the trawl and none in the grabs. On the photographs only two individuals could be distinguished, but small specimens could easily have been obscured by the overlying brittle-stars. This, together with the fact that a Chlamys was usually counted only if both valves could be seen makes it probable that the photographic count is an underestimate.

Among other animals, a flatfish was seen on one print, but no fish were taken by the grabs. In general, however, the fish which the trawl showed to be present in small numbers-codling and Gadus minutus_-would be difficult to see in photographs. On the soft ground the grab took two Cyprina islandica and one Aphrodite aculeata. Neither of these was found in the trawl, but although they could not be seen on photographs, numerous tracks were noticed on the mud (e.g. Pl. IB), and many small holes, probably breathing apertures. Lastly, the following echinoderms were 'taken' by the three gears:

\begin{tabular}{lrcc} 
& \multicolumn{3}{c}{ Totals observed } \\
\cline { 2 - 4 } & Trawl & Grab & Prints \\
Solaster papposus & 24 & I & 4 \\
Palmipes membranacea & 3 & 0 & 0 \\
& I & 0 & 0
\end{tabular}

\section{EXPLANATIONS OF PLATES I AND II}

Underwater photographs, each covering approximately $\frac{2}{3} \mathrm{~m}^{2}$ of the sea bottom. Each represents one print used in counting, except that trimming has reduced it by about $5 \%$. The weight for operating the trigger mechanism can be seen on each print. This was $7 \mathrm{~cm}$ in diameter.

P1. I. Lynn of Lorne, stretch A: A, showing the sandy area of this stretch and the typical distribution of brittle-stars found in it; $\mathrm{B}$, showing the muddy area, with tracks.

Pl. II. Loch Creran: A, stretch B, showing the epifauna mainly of brittle-stars and ascidians; $\mathrm{B}$, stretch C, coarse deposit where grabbing was difficult, showing Chlamys opercularis, starfish and a spider crab. 

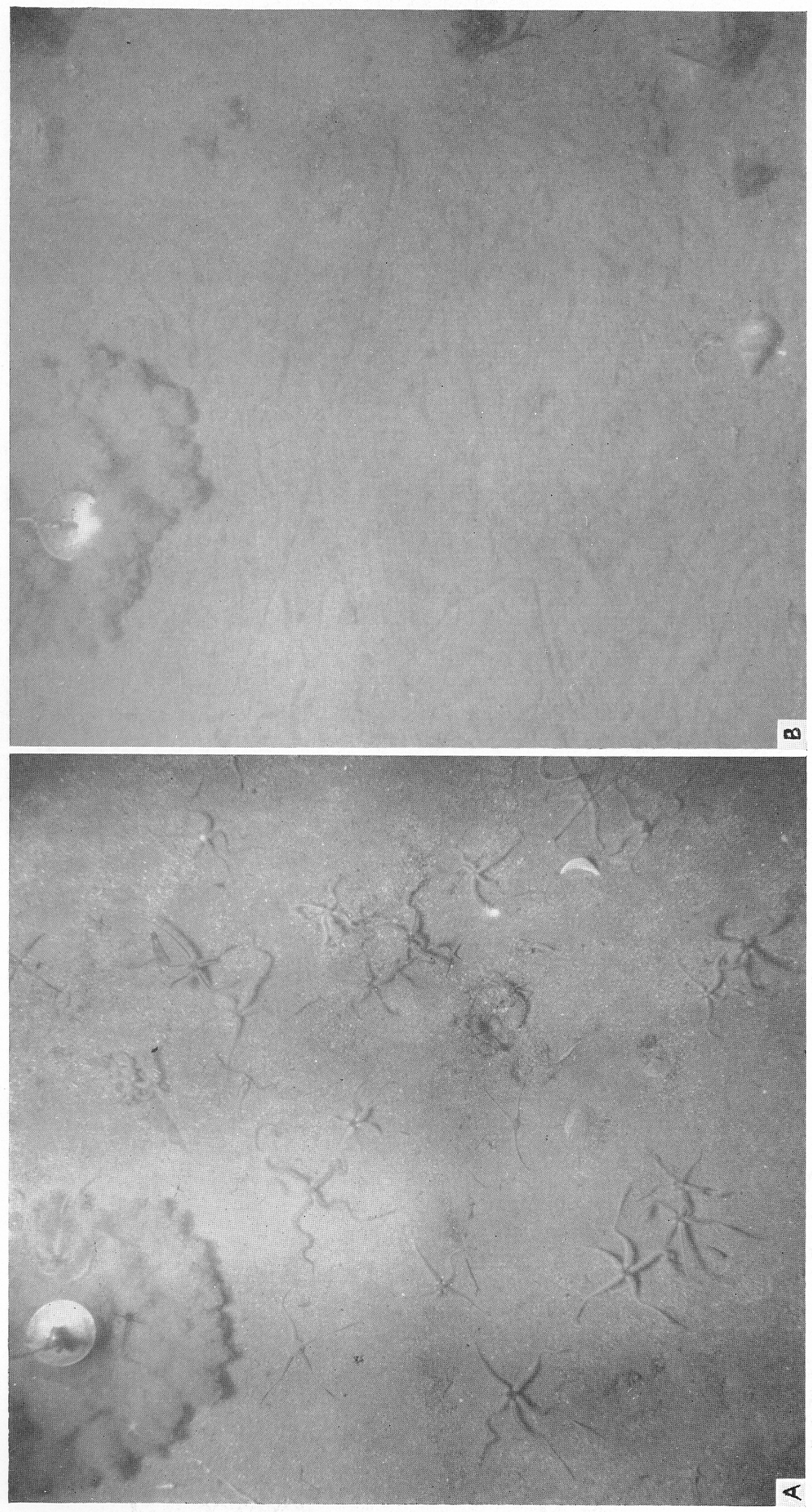

(Facing p. 422) 

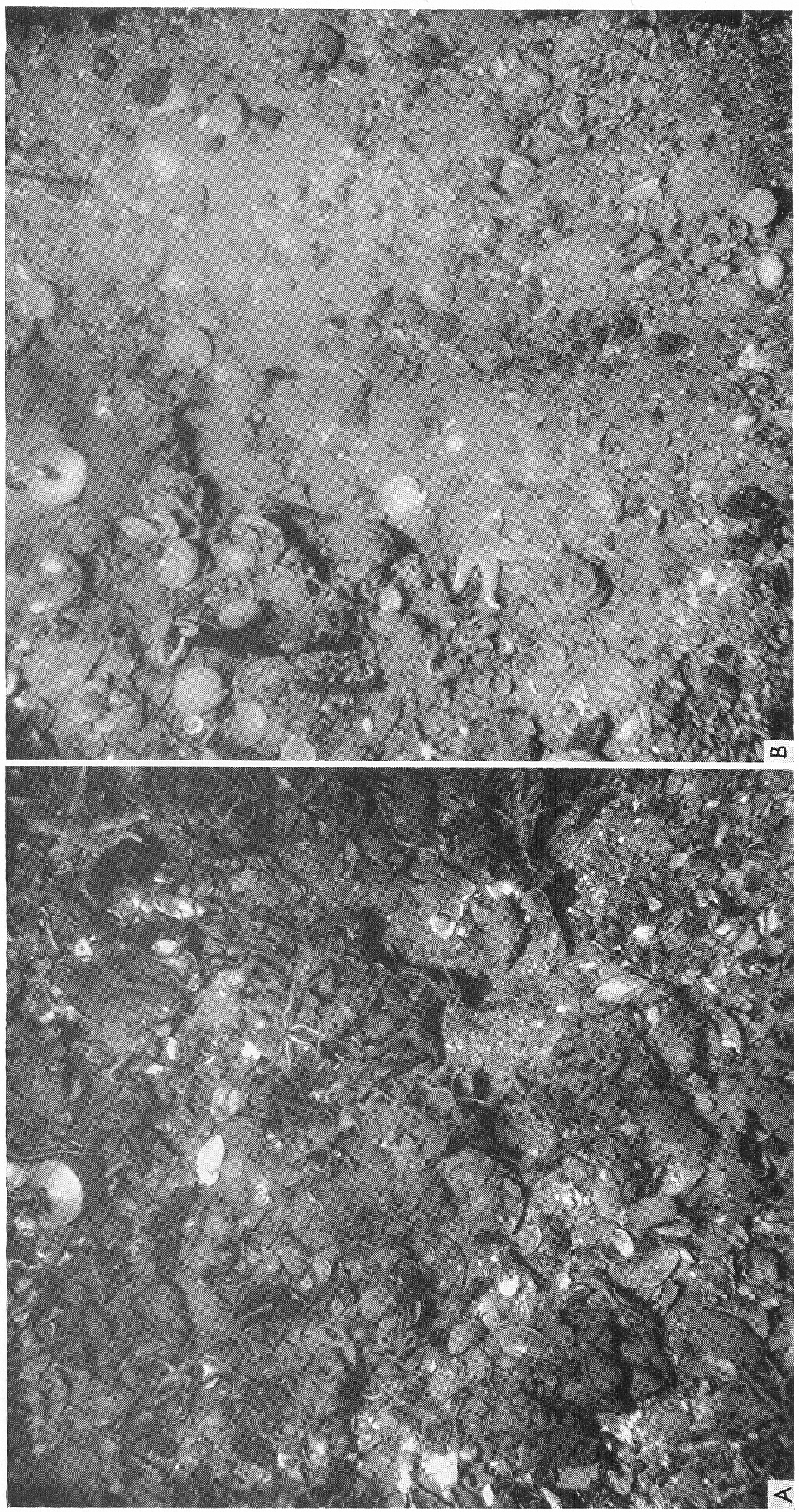


\section{Stretch $B$ (Pl. II A)}

This was across the entrance to Loch Creran in $15-22 \mathrm{~m}$. The dans were $464 \mathrm{~m}$ apart, and the area swept by the trawl $\left(848 \mathrm{~m}^{2}\right)$ was covered by sixteen photographs and eighteen grab samples. The photographs showed a fairly uniform stretch of coarse material-sand mixed with stones and shells, with an epifauna of brittle-stars and ascidians.

Ophiothrix fragilis occurred on all the photographs from this stretch, ranging in number from four to seventy-two per print, with a mean of twentyseven. In the grabs, Ophiothrix was found in eleven of the eighteen samples, ranging from one to seventeen per sample, with a mean of 4.9 individuals. The calculated numbers for the whole stretch are 32,702 for the camera and 4I,9I9 for the grab, while the trawl caught 1992.

Lima hians, a lamellibranch which builds a nest among stones and shells, was abundant. Eighty-three were found in the trawl and seven were taken in four grab samples. A nesting animal such as this is difficult to detect on photographs, and only one could be distinguished.

The only natantian decapods found were five Pandalus taken in the trawl. The remaining decapods in the trawl consisted of six Eupagurus bernhardus, eight Hyas araneus and fifteen small spider crabs, mostly Inachus. The camera showed four decapods in four prints. Three were spider crabs and the fourth a Eupagurus.

Other animals occurring in smaller numbers were as follows:

\begin{tabular}{lccc} 
& \multicolumn{3}{c}{ Totals observed } \\
Arawl & Grab & Prints \\
Henrias rubens & 5 & 0 & 8 \\
Echinoidea & 5 & $\mathrm{I}$ & $\mathrm{I}$ \\
Holothuroidea & 36 & 3 & 0 \\
Chlamys opercularis & 0 & $\mathrm{I}$ & 0 \\
Buccinum undatum & 4 & 0 & 6 \\
Lamellibranchs & 2 & 0 & 2 \\
Goby & 0 & 2 & 0 \\
& 2 & 0 & 0
\end{tabular}

Stretch $C$ (P1. II в)

The dans were placed in I I-28 m depth along the south shore of the loch, and were $579 \mathrm{~m}$ apart. The area covered by the Agassiz was $1059 \mathrm{~m}^{2}$, and was represented by twenty-four photographs and fifteen grabs. The stretch consisted of coarse gravel and stones of various sizes, with some large boulders here and there. Only three of the grab hauls produced fauna-eight Ophiothrix three Lima and one ascidian. At all the other attempts either the jaws were held open by stones, or the grab was empty, presumably having landed on large boulders. After several further attempts, grab sampling on this stretch was abandoned. On such ground the trawl sampling also is probably far from 
optimum, and the camera is the one instrument which can operate satisfactorily. The trawl and camera results are considered below.

Ophiothrix fragilis was absent from the first seven prints, although the ground here, except for the presence of a few fragments of algae, appeared to be similar to that of the remainder of the stretch. All the other prints showed Ophiothrix in numbers varying from one to forty-two, the mean for all prints being ten. This gives an estimate of 15,577 for the whole area, compared with the trawl catch of 215 .

Chlamys opercularis was distributed over the whole area. Twenty-eight individuals were observed on eleven prints in numbers varying from one to ten per print. The estimate for the whole area is 1766 compared with the trawl catch of twenty-seven.

Of the decapods taken in the trawl, thirty-eight were Pandalus montagui, and none of these was seen on photographs. Natantian decapods in general probably merge with their surroundings so well that they would be difficult to distinguish on prints. It should be noted that the gear described here is triggered when a weight hits the bottom. The slight interval between the landing of the weight and the taking of the photograph might allow a rapidly moving animal to leave the field. Modification of the camera release would obviate this. The remaining trawl-caught decapods consisted of three Eupagurus bernhardus, eleven large Hyas araneus and six small spider crabs (Inachus and Macropodia). Twelve decapods could be seen on ten photographs-one Eupagurus and eleven spider crabs, mostly Hyas. These spider crabs were distributed fairly evenly over the ground, and the calculated population for the whole area is 694 .

Twenty specimens of echinoids were taken in the trawl, and twelve were seen in five photographs. These five photographs were all from a small area at the beginning of the stretch, and on any one print the echinoids usually occurred together and in association with pieces of Laminaria.

Other animals are as follows:

\begin{tabular}{|c|c|c|c|c|c|}
\hline \multirow[b]{3}{*}{ Lima } & \multicolumn{2}{|c|}{ Totals observed } & & \multicolumn{2}{|c|}{ Totals observed } \\
\hline & Trawl & Camera & & Trawl & Camera \\
\hline & 35 & - & Henricia & 2 & I \\
\hline Buccinum & I & 2 & Sabellids & - & 9 \\
\hline Pecten & 2 & 一 & Ascidians & $2 \mathrm{I}$ & 6 \\
\hline Asterias & 2 & 2 & Flatfish & I & 一 \\
\hline
\end{tabular}

The nine sabellids all occurred in one small isolated patch of soft ground seen on one print. A number of Pecten shells were seen on prints, but since these appeared to be flat on the bottom they were not counted as being living animals.

Stretch D (P1. IIIA)

This extended from the entrance along the north shore of Loch Creran, at a depth of $20-28 \mathrm{~m}$. The dans were $4 \mathrm{I} 7 \mathrm{~m}$ apart, giving $763 \mathrm{~m}^{2}$ as the area 
trawled, and this area was covered by twenty-six photographs and twenty grabs. The stretch had a fairly uniform bottom of sandy gravel and small stones, with a more or less continuous covering of mussel shells. The most abundant animals were brittle-stars and decapod crustaceans.

Ophiothrix fragilis was fairly evenly dispersed over the ground. It was present on all prints in numbers between twenty-one and seventy-six, with a mean of fifty-six per print. It was also present in all the grab samples, varying from two to thirty-six per sample, with a mean of 10.5 . The camera and grab estimates for the whole stretch are 6I,330 and 79,686 respectively, compared with 524 individuals taken by the trawl.

Again natantian decapods could not be seen in photographs, although thirtyeight Pandalus were found in the trawl and two in the grab samples. The trawl took five large Hyas araneus and twenty-one other small spider crabs, and three Eupagurus, while three Hyas were caught in the grab. Two Eupagurus were seen on the photographs and nineteen spider crabs, mostly Hyas. The spider crabs were distributed fairly evenly over the stretch occurring on sixteen of the twenty-six prints, giving an estimate of 796 individuals for the whole stretch.

Ascidians were mostly species of Ascidiella and Ciona and thirty-seven were seen in fifteen prints, in numbers ranging from one to five per print. They were also found in thirteen of the twenty grabs, the total number being twenty-three. Estimates for the whole area amount to 1550 individuals for the camera, and 8769 for the grab. The trawl took six specimens.

Thirty-one Lima hians were taken in thirteen grab samples, ranging from one to five per sample. Only eight specimens were taken in the trawl. Trawl catches of Lima are likely to be very variable, depending on the extent to which the trawl bites into the bottom. No Lima were seen on the prints.

Seven mussels were taken in the trawl and thirteen in nine grabs. On the photographs almost every print showed mussel shells, and in several prints two closed valves could be seen. These lay singly or in small groups, not in a continuous bed. It was, however, difficult to decide if these animals were alive, and mussels were therefore not counted.

The following other animals were found in the three gears:

\begin{tabular}{lrcc} 
& \multicolumn{3}{c}{ Totals observed } \\
\cline { 2 - 4 } Chlamys & Trawl & Grab & Prints \\
Buccinum & I2 & 2 & - \\
Echinoids & I & I & 2 \\
Asterias rubens & I & 5 & 4 \\
Solaster & - & 4 & 8 \\
Fish & - & & I \\
& 4 & 5 & I
\end{tabular}

Stretch $E(\mathrm{Pl}$. IIIB)

This was a continuation of stretch D along the north shore of the loch in 26-3I m. The distance between dans was $834 \mathrm{~m}$, and the area swept by the 
trawl $1525 \mathrm{~m}^{2}$. This area was covered by fifty-seven prints and twenty grabs. Two distinct types of bottom were encountered. About a third of the stretch consisted of sandy gravel with large stones here and there. This merged into mud which covered the remainder of the stretch, except for a few small patches of muddy sand. The prints showed that most of the epifauna occurred on the gravel.

Ophiothrix fragilis occurred only on the area of sand and gravel, which was covered by the first twenty prints, and the numbers were lower than on any of the other stretches. They were seen on fifteen of the twenty prints in numbers varying from two to forty per print, with a mean of eight. Five of the grabs were on the sandy area, and took a total of twelve Ophiothrix. The estimates for the whole gravel area for camera and grab are 4916 and Io,455 respectively. The trawl took 290 Ophiothrix.

Chlamys opercularis was distributed over the whole area but was more numerous on the gravel than on the mud. No Chlamys were taken by the grab. Photographs showed twenty-five individuals in fifteen prints, varying in number from one to four per print, and giving an estimate for the whole area of 956 Chlamys. The number taken by the trawl was II8.

Eleven Pandalus and three Crangon were taken by the trawl, but no natantian decapods were recorded from grabs or photographs. The Reptantia, however, were numerous. Forty-eight spider crabs, mostly small, thirty-five eupagurids and one Munida were taken in the trawl. In the grab samples only one Eupagurus and one Galathea were taken. Twelve crabs were noted in ten prints-five spider crabs and seven Eupagurus. The spider crabs were mostly large Hyas, and the population of small spider crabs sampled by the trawl could not be estimated from photographs.

Other animals which occurred in smaller numbers were as follows:

\begin{tabular}{lrcc} 
& \multicolumn{3}{c}{ Totals observed } \\
Pennatulacea & Trawl & Grabs & Prints \\
Pecten & - & - & I \\
Mussel & $\mathrm{I}$ & - & 2 \\
Cockle & $\mathrm{I} 3$ & - & + \\
Asterias rubens & 2 & $\mathrm{I}$ & - \\
Solaster endica & Io & - & I \\
Solaster papposus & 3 & - & $\mathrm{I}$ \\
Henricia & 2 & - & 4 \\
Palmipes & $\mathrm{I}$ & - & $\mathrm{I}$ \\
Ascidians & $\mathrm{I}$ & - & - \\
Fish & - & & 3 \\
& $\mathrm{I} 6$ & - & $\mathrm{I}$
\end{tabular}

The ascidians in the grabs were taken in two clumps in two consecutive hauls, and those in photographs were on consecutive prints, suggesting that these animals were localized in a small part of the stretch, which could account for their absence from the trawl. The fish consisted mainly of gobies and flatfish. 


\section{Discussion}

In considering three gears as different as trawl, grab and camera it is obvious that direct comparisons cannot be made. Each gear has its own peculiarities which give it advantages and limitations not possessed by the others. In dealing with the epifauna one of the important factors is the area of bottom which can be conveniently sampled. Thus between two dans in the present work, the trawl in half an hour could cover $2000 \mathrm{~m}^{2}$ of bottom, the camera in the same time photographed $50 \mathrm{~m}^{2}$ and the grab in half an hour generally sampled abour $2 \mathrm{~m}^{2}$.

Since the trawl covers a large area it is useful in sampling organisms which are few in number and widely dispersed. Further, it can take large animals, and also active ones such as natantian decapods. But the trawl gives no indication of the distribution of the animals within the limits of the comparatively extensive ground covered in any one haul. A series of grab samples can give information on distribution, but since each sample covers so small an area, an impossibly large number of samples would be required before grab results for less numerous animals could be applied to a wide area. The camera is intermediate between the trawl and grab in that it can cover a fairly wide area yet indicate in considerable detail the distribution of the animals. On stretch C, for example, the trawl showed merely the presence of Chlamys opercularis and of Echinoidea. The camera, however, established that while the former species was distributed fairly evenly over the whole stretch, the latter group was confined to a small area, and even there occurred only in association with Laminaria.

In practice, the relative effectiveness of the three gears will vary with the numerical density of any particular species, and with its distribution over the whole area studied. The most abundant animal in the present work was Ophiothrix fragilis, and the various estimates of the numbers of this species on the five stretches are given in Table II.

\begin{tabular}{|c|c|c|c|}
\hline \multicolumn{4}{|c|}{ Estimated By the Three Gears } \\
\hline Stretch & Trawl & Camera & Grab \\
\hline $\begin{array}{l}\mathrm{A} \\
\mathrm{B} \\
\mathrm{C} \\
\mathrm{D} \\
\mathrm{E}\end{array}$ & $\begin{array}{r}1093 \\
1992 \\
215 \\
524 \\
290\end{array}$ & $\begin{array}{r}39,542 \\
32,702 \\
15,577 \\
61,330 \\
4,916\end{array}$ & $\begin{array}{c}\text { 19,418 } \\
41,919 \\
\text { (No samples) } \\
79,686 \\
10,455\end{array}$ \\
\hline
\end{tabular}

The trawl always gave the lowest estimate. The camera values are from I6 to II 7 times greater, and the grab values from I8 to I 52 times greater than those of the trawl. Comparing the camera and the grab, it can be seen that on stretch A the camera estimate is higher, while on the other four stretches the grab gives a rather greater value. The difference between stretch $\mathrm{A}$ and the 
other grounds with regard to the relative estimates of camera and grab is connected with a difference in the distribution of the animals (cf. Pls. I A and IV). In the Lynn of Lorne generally (where stretch A is located), the brittle-stars are found not in dense masses but either as single individuals (P1. IA), or in small clumps of up to five or six individuals. With such a distribution there are large patches of bare ground and the grab will tend to underestimate the number present. The camera, on the other hand, covering a larger area, gives a better estimate. In Loch Creran, however, the brittle-stars occurred in dense masses (P1. IV) or at least as a fairly even covering over the ground (P1. IIIA). For such distributions the grab gave rather higher estimates than the camera, probably partly because in counting brittle-stars in prints the general practice was to count an animal only when the disc could be seen. Thus when the animals are aggregated, often several individuals thick, the discs of animals in the lower layers tend to be obscured and an underestimate results. It should be noted, however, that although in these conditions the camera may give a slightly lower estimate than the grab, it is a much less variable, and therefore more reliable estimate. On stretch $\mathrm{D}$, for example, where the densest population of brittle-stars was found, the coefficient of variation of the grab counts was $85 \%$, while the corresponding value for the camera was only $25 \%$.

The other animals of the epifauna were all considerably less abundant than Ophiothrix, and usually occurred as single individuals often widely separated from each other. For animals distributed in this way the grab is generally the least efficient of the three gears, since, covering such a small area, it takes too few individuals to allow valid estimates to be made for the whole ground. The trawl is better, mainly because it covers considerably more ground. The best results were usually from the camera. For example, in stretch $\mathrm{D}$, only three of the twenty grab samples contained spider crabs, while sixteen of the twentysix photographs showed these animals, giving an estimate of 796 individuals for the whole area, compared with the trawl catch of twenty-six. Another species on which the camera gave useful information was Chlamys opercularis, and the estimated numbers of this species on each stretch are shown in Table III. The camera not only most often gave higher estimates, but also gave information not obtained from the other gears. It showed on stretch E, for example, that Chlamys was distributed over the whole stretch; that it was more abundant on the gravel than on the mud, and that its density varied from one to four individuals per square metre.

EXPLANATION OF PLATES III AND IV

Underwater photographs, those on Pl. III covering approximately $\frac{2}{3} \mathrm{~m}^{2}$ of the sea bottom, as in Pls. I and II; that on Pl. IV about $\frac{7}{10} \mathrm{~m}^{2}$. The weight for operating the trigger mechanism, seen on each print, was $7 \mathrm{~cm}$ in diameter.

P1. III. Loch Creran: A, stretch D, showing the covering of mussel shells; B, stretch E, showing the coarse deposit with Chlamys opercularis.

Pl. IV. Example of the aggregation of brittle-stars found on several stretches in Loch Creran. 

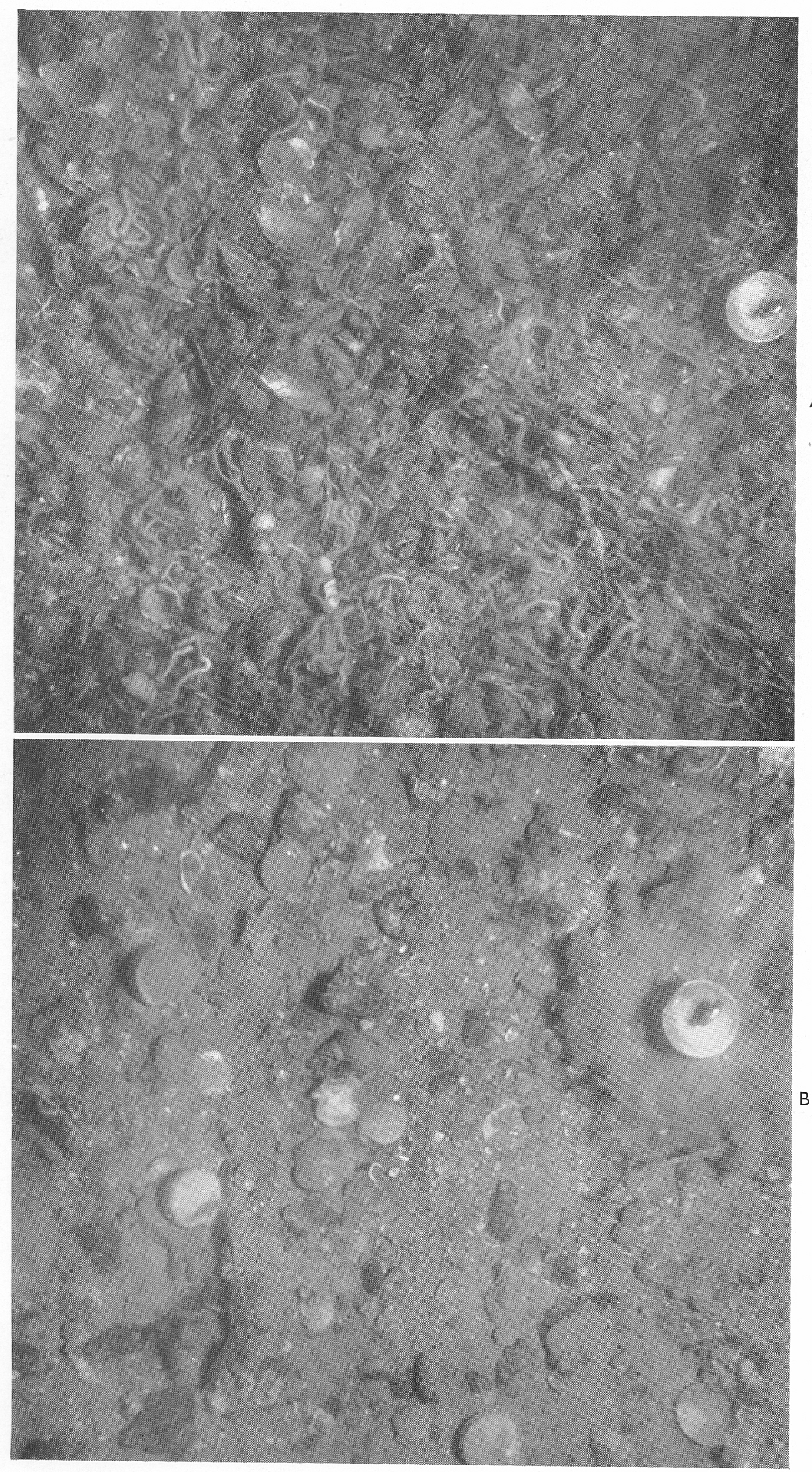


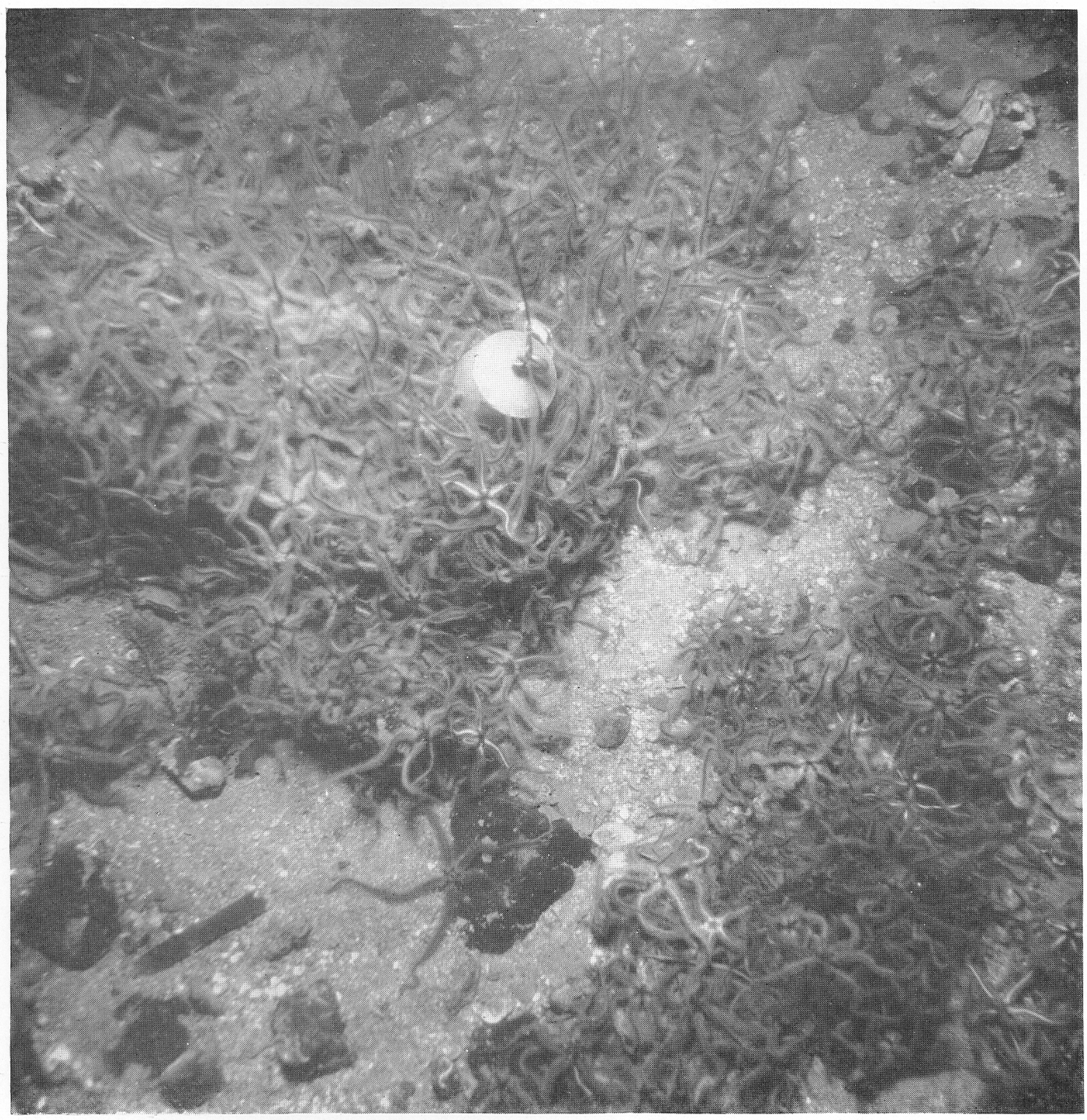


TABle III. Numbers of ChLAMYS OPERCULARIS ON EACH Stretch aS ESTIMATED BY THE THREe GeARS

$\begin{array}{cccc}\text { Stretch } & \text { Trawl } & \text { Camera } & \text { Grab } \\ \text { A } & 23 & 85 & \circ \\ \text { B } & 4 & 454 & \circ \\ \text { C } & 27 & \text { I766 } & \text { No samples } \\ \text { D } & \text { I2 } & \circ & 763 \\ \text { E } & \text { II } 8 & 956 & 0\end{array}$

Finally, it should be noted that the use of the camera is limited to areas of fairly clear water. It is difficult to obtain clear pictures, for example, in the turbid water of Aberdeen Bay, and off some parts of the south-west Scottish coast.

\section{SUMMARY}

Agassiz trawl and Van Veen grab catches of certain animals of the epifauna are compared with numbers of these animals estimated from underwater photographs.

In sampling brittle-stars, which occurred in large numbers, the Agassiz trawl was the least efficient of the three gears. When the brittle-stars were distributed singly or in small patches the camera gave better results than the grab. When the patches were large, or when the distribution was more or less continuous, the grab gave slightly higher estimates, but its estimates were considerably more variable than those of the camera.

For the less common animals of the epifauna the grab was generally a poor sampling instrument. The trawl was rather better, but within fairly wide limits it can give no indication of distribution. The camera gave more acceptable estimates and also indicated the distribution of the animals over the ground.

For certain areas of hard bottom the camera is probably the only instrument which can give adequate results.

\section{REFERENCES}

Marine Biological Association, i931. Plymouth Marine Fauna, and edition.

Vevers, H. G., I951. Photography of the sea floor. F. mar. biol. Ass. U.K., Vol. 30, pp. IOI-II.

- - 1952. A photographic survey of certain areas of the sea floor near Plymouth. F. mar. biol. Ass. U.K., Vol. 31, pp. 215-2I. 